\title{
Roseovarius nanhaiticus sp. nov., a member of the Roseobacter clade isolated from marine sediment
}

Correspondence

Zongze Shao

shaozz@163.com

\author{
Baojiang Wang, † Fengqin Sun,t Qiliang Lai, Yaping Du, Xiupian Liu, \\ Guangyu Li, Jie Luo and Zongze Shao
} Key Laboratory of Marine Biogenetic Resources, Third Institute of Oceanography, State Oceanic
Administration, PR China

\begin{abstract}
An aerobic, Gram-staining-negative, rod or ovoid-shaped bacterial isolate, strain $\mathrm{NH}^{2} \mathrm{~J}^{\top}$, was isolated from a sandy sediment sample from the South China Sea. Strain $\mathrm{NH}_{52} \mathrm{~J}^{\top}$ exhibited tumbling motility, formed beige or faint pink colonies, gave a positive reaction in tests for catalase and oxidase and required $\mathrm{NaCl}$ for growth. Optimal growth was observed at $\mathrm{pH} 7.8-9.3$, at $30{ }^{\circ} \mathrm{C}$ and in the presence of $2.0-4.0 \%(\mathrm{w} / \mathrm{v}) \mathrm{NaCl}$. The novel strain did not synthesize bacteriochlorophyll $a$, and the DNA G $+\mathrm{C}$ content was $62 \%$. The major fatty acids were $\mathrm{C}_{18: 1} \omega 7 c, \mathrm{C}_{16: 0}$ and $\mathrm{C}_{18: 1} \omega 7 c$ 11-methyl. Phylogenetic analysis based on 16S rRNA gene sequences indicated that strain $\mathrm{NH}_{52} \mathrm{~J}^{\top}$ was affiliated to the genus Roseovarius of the class Alphaproteobacteria. Roseovarius pacificus and Roseovarius aestuarii were the most closely related recognized species to strain $\mathrm{NH}_{52} \mathrm{~J}^{\top}$ with $16 \mathrm{~S}$ rRNA gene sequence similarity values of 95.0 and $95.7 \%$, respectively. Sequence similarity values between strain $\mathrm{NH}_{52} \mathrm{~J}^{\top}$ and other phylogenetically related species were all below $95.0 \%$. Based on the phenotypic, chemotaxonomic and phylogenetic data presented, strain $\mathrm{NH}_{5} 2 \mathrm{~J}^{\top}$ is considered to represent a novel species of the genus Roseovarius, for which the name Roseovarius nanhaiticus sp. nov. is proposed. The type strain is $\mathrm{NH}^{2} 2 \mathrm{~J}^{\top}\left(=\mathrm{LMG} 24840^{\top}=\mathrm{CCTCC}\right.$ AB $208317^{\top}=\mathrm{MCCC}$

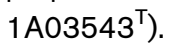

The genus Roseovarius comprised six recognized species at the time of writing: Roseovarius tolerans (Labrenz et al., 1999), Roseovarius nubinhibens (González et al., 2003), Roseovarius crassostreae (Boettcher et al., 2005), Roseovarius mucosus (Biebl et al., 2005), Roseovarius aestuarii (Yoon et al., 2008) and Roseovarius pacificus (Wang et al., 2009). The genus Roseovarius accommodates Gram-negative, ovoid or rod-shaped, obligate aerobic alphaproteobacteria and all its members are positive in tests for catalase. All of the species were retrieved from marine environments and belong to the Roseobacter group. Many novel representatives of this group have been isolated from marine habitats all over the world and described recently (Wagner-Döbler et al., 2003; Buchan et al., 2005; Dai et al., 2006; Lee et al., 2007; Hwang \& Cho, 2008). In this paper, a novel Gram-negative, beige- to slightly pink-pigmented, aerobic bacterium is described that was isolated from sediment of the South China Sea. By using 16S rRNA gene sequence phylogenetic analysis, the new strain was determined to be a member of the Roseobacter group, in which it formed a distinct lineage

†These authors contributed equally to this work.

Abbreviation: Bchl a, bacteriochlorophyll $a$.

The GenBank accession number for the 16S rRNA gene sequence of Roseovarius nanhaiticus sp. nov. NH52J is FJ403243. with members of the genus Roseovarius. Based on differences in fatty acid composition, physiological and biochemical characteristics, morphological features, and phylogenetic analysis as described in this study, the new strain should be classified as a novel species of the genus Roseovarius.

Recently, bacterial diversity investigations have led to the discovery of many novel species and genera from the South China Sea. One of these strains, designated $\mathrm{NH}_{52} \mathrm{~J}^{\mathrm{T}}$, was isolated from a brown sandy sediment sample $\left(109^{\circ} 40.102^{\prime} \mathrm{E}, 06^{\circ} 5.901^{\prime} \mathrm{N}\right)$, which was collected at water depth of $157 \mathrm{~m}$ in June 2007. In the laboratory, the sediment sample was suspended and diluted $(1: 100)$ using sterilized seawater, spread onto M2 agar plates and then incubated at $25{ }^{\circ} \mathrm{C}$ for 1 week. The composition of $\mathrm{M} 2$ medium was $\left(1^{-1}\right.$ seawater): $5 \mathrm{~g} \quad \mathrm{CH}_{3} \mathrm{COONa}, 0.5 \mathrm{~g}$ peptone, $0.5 \mathrm{~g}$ yeast extract, $0.5 \mathrm{~g}$ glucose, $0.5 \mathrm{~g}$ sucrose, $0.5 \mathrm{~g}$ starch, $0.05 \mathrm{~g}$ trisodium citrate, $0.05 \mathrm{~g}$ malic acid, $0.05 \mathrm{~g}$ potassium sodium tartrate, $1.0 \mathrm{~g} \mathrm{NH}_{4} \mathrm{NO}_{3}, 0.2 \mathrm{~g}$ $\mathrm{NH}_{4} \mathrm{Cl}$ and $15 \mathrm{~g}$ agar, adjusted to $\mathrm{pH}$ 7.5-7.6. Strain $\mathrm{NH}_{52} \mathrm{~J}^{\mathrm{T}}$ was picked and streaked on fresh M2 agar medium. This process was repeated three times for purification and the strain was preserved as a $20 \%(\mathrm{v} / \mathrm{v})$ glycerol suspension at $-80{ }^{\circ} \mathrm{C}$. Cell morphology and motility were observed by phase-contrast microscopy 
Table 1. Phenotypic characteristics that differentiate strain $\mathrm{NH}_{52} \mathrm{~J}^{\top}$ from the closely related recognized species of the Roseobacter clade


Leisingera methylohalidivorans $\mathrm{MB}^{\mathrm{T}} ; 9$, Phaeobacter gallaeciensis $\mathrm{BS} 107^{\mathrm{T}} ; 10$, Marinovum algicola ATCC $51440^{\mathrm{T}}$. Data for reference type strains are from Yoon et al. (2008), Biebl et al. (2005), Labrenz et al. (1999), González et al. (2003), Boettcher et al. (2005), Martínez-Cánovas et al. (2004), Martens et al. (2006), Schaefer et al. (2002), Ruiz-Ponte et al. (1998), Lafay et al. (1995) and this study. All strains were positive in tests for catalase and all strains have a requirement for $\mathrm{Na}^{+}$ions for growth. +, Positive; -, negative; $\mathrm{W}$, weakly positive; $\mathrm{V}$, variable; $\mathrm{ND}$, no data available; $\mathrm{NF}$, not found.

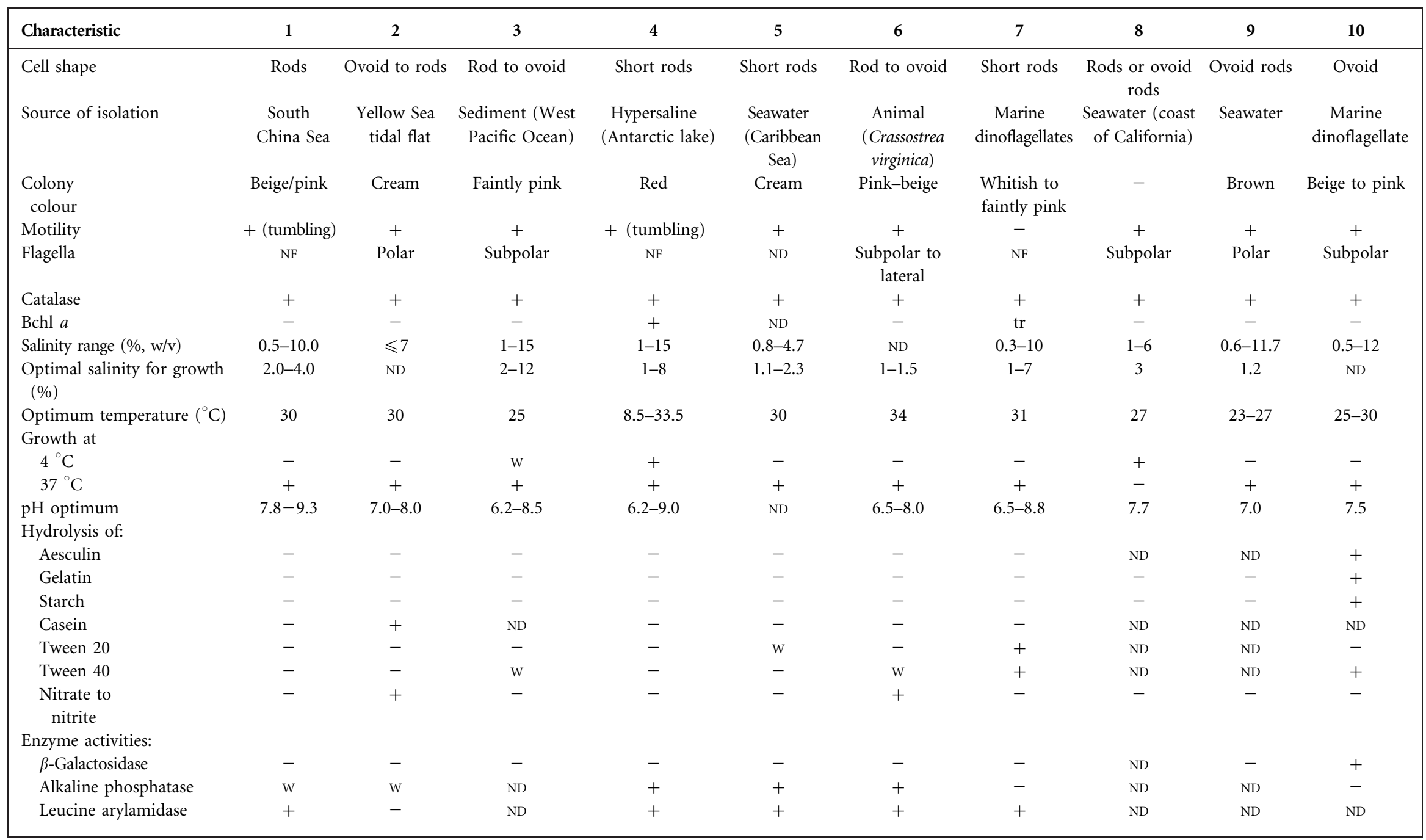




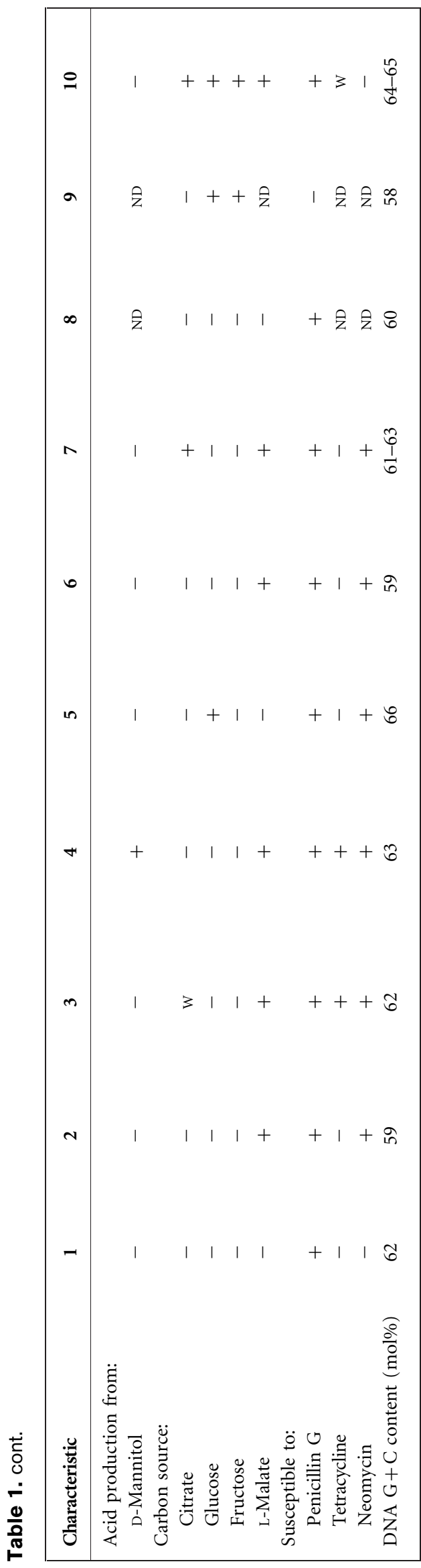

(model 50i; Nikon) and transmission electron microscopy (model JEM-1230; JEOL) using cells from the early exponential phase grown at $30{ }^{\circ} \mathrm{C}$ for 2 days.

The temperature range for growth was determined between 4 and $45{ }^{\circ} \mathrm{C}$. The initial growth $\mathrm{pH}$ range $(3-10)$ was determined using $5 \mathrm{ml}$ HLB medium supplemented with $200 \mu \mathrm{l} \mathrm{M} 2$ medium, adjusted with $\mathrm{NaOH}(5 \mathrm{M})$ and $\mathrm{HCl}$ (5 M) solution. HLB medium was modified from LuriaBertani (LB) medium (Sambrook et al., 1989), with the concentration of $\mathrm{NaCl}$ increased to $30 \mathrm{~g} \mathrm{l}^{-1}$. The salinity range supporting growth was determined at various $\mathrm{NaCl}$ concentrations $(0.5-25 \%, w / v)$ in M2 medium. The requirement for $\mathrm{NaCl}$ was determined in $\mathrm{M} 2$ medium lacking $\mathrm{Na}^{+}$. The salinity and $\mathrm{pH}$ range experiments were conducted with an incubation temperature of $30^{\circ} \mathrm{C}$. Growth was measured by using a spectrophotometer at $600 \mathrm{~nm}$ after incubation for 2 days. Gram-staining was performed as described by Gerhardt et al. (1994). The oxidase reaction was tested by using oxidase reagent (bioMérieux). Catalase activity was tested using a $3 \%$ $\mathrm{H}_{2} \mathrm{O}_{2}$ solution. Hydrolysis of starch, casein, Tween 20, 40 and 80 were determined as described by Cowan \& Steel (1965). Other physiological and biochemical tests were performed using API 20NE, API 20E and API ZYM strips (bioMérieux). The inoculum was prepared by suspending cells in a $3 \%(\mathrm{w} / \mathrm{v}) \mathrm{NaCl}$ solution and the salinity of the API AUX medium was also increased to $3 \%$. Production of bacteriochlorophyll $a$ (Bchl $a$ ) was determined by spectrophotometric analysis as described by Martens et al. (2006). The results are presented in Table 1.

Susceptibility to antibiotics was tested on M2 agar plates by using the following discs (Oxoid; $\mu \mathrm{g}$ per disc unless otherwise specified): ceftriaxone (30), cephradine (30), chloramphenicol (30), gentamicin (10), erythromycin (15), cefoperazone (75), ciprofloxacin (5), clindamycin (2), doxycycline hydrochloride (30), neomycin (10), tetracycline (30), cephalexin (30), ampicillin (10), furazolidone (15), metronidazole (5), cephazolin (30), lincomycin (2), minocycline (30), norfloxacin (10), kanamycin (30), vancomycin (30), trimethoprim (25), piperacillin (100), ofloxacin (5), rifampicin (5), carbenicillin (100), polymyxin B (300 U), streptomycin (10), oxacillin (1) and penicillin $\mathrm{G}(10 \mathrm{U})$. All of the test plates were incubated at $30{ }^{\circ} \mathrm{C}$ for 2 days.

For cellular fatty acid analysis, strain $\mathrm{NH}^{2} \mathrm{~J}^{\mathrm{T}}$ was harvested from MA plates after cultivation for 3 days at $30^{\circ} \mathrm{C}$. The fatty acids were extracted according to the standard protocol of the Microbial Identification System (MIDI, Sherlock). Analysis of the fatty acid methyl esters was performed by GC (6850, Agilent) and peaks were identified with MIDI software (version 6.0). The predominant cellular fatty acids of strain $\mathrm{NH}_{52} \mathrm{~J}^{\mathrm{T}}$ were straight-chain unsaturated and saturated fatty acids, methylated fatty acids and hydroxy fatty acids. Fatty acids that constituted $>5 \%$ of the total were $\mathrm{C}_{18: 1} \omega 7 c(50.4 \%), \mathrm{C}_{16: 0}(18.6 \%)$, $\mathrm{C}_{12: 0}(9.2 \%), \mathrm{C}_{18: 1} \omega 7 c 11$-methyl $(9.3 \%)$ and $\mathrm{C}_{12: 0} 3-\mathrm{OH}$ 
(5.3\%). A relatively large amount of $\mathrm{C}_{18: 1} \omega 7 c$ is one feature found for the majority of species within the class Alphaproteobacteria (Martens et al., 2006). The major fatty acid profile was similar to those of recognized species of the genus Roseovarius (Table 2).

The genomic DNA of strain $\mathrm{NH}_{52} \mathrm{~J}^{\mathrm{T}}$ was extracted according to the method described by Ausubel et al.

Table 2. Comparison of the cellular fatty acid contents (\%) of strain $\mathrm{NH}_{52} \mathrm{~J}^{\top}$ with recognized species of the genus Roseovarius

Strains: $1, \mathrm{NH}^{2} \mathrm{~J}^{\mathrm{T}}$ (data from this study); 2, Rva. aestuarii SMK-122 ${ }^{\mathrm{T}}$; 3, Rva. tolerans DSM $11457^{\mathrm{T}}$; 4, Rva. nubinhibens DSM $15170^{\mathrm{T}} ; 5$, Rva. crassostreae CV919-312 ${ }^{\mathrm{T}}$; 6, Rva. mucosus DFL-24 ${ }^{\mathrm{T}}$. Data for reference type strains are from Yoon et al. (2008). Cell mass of strain $\mathrm{NH}_{52} \mathrm{~J}^{\mathrm{T}}$ and for the type strains of the five species of the genus Roseovarius was harvested from MA plates after cultivation for 3 days at $30{ }^{\circ} \mathrm{C}$ (Yoon et al., 2008). ECL, equivalent chain-length.

\begin{tabular}{|c|c|c|c|c|c|c|}
\hline Fatty acid & 1 & 2 & 3 & 4 & 5 & 6 \\
\hline \multicolumn{7}{|c|}{ Straight-chain saturated fatty acids } \\
\hline $\mathrm{C}_{12: 0}$ & 9.2 & 5.1 & & 5.1 & & 6.6 \\
\hline $\mathrm{C}_{14: 0}$ & 0.5 & & & & & \\
\hline $\mathrm{C}_{15: 0}$ & & 0.2 & 1.9 & 0.6 & & \\
\hline $\mathrm{C}_{16: 0}$ & 18.6 & 16.2 & 10.3 & 13.8 & 11.8 & 8.1 \\
\hline $\mathrm{C}_{17: 0}$ & & 0.3 & 5.8 & 0.6 & 0.3 & 0.3 \\
\hline $\mathrm{C}_{18: 0}$ & 0.7 & 1.0 & 1.2 & 0.9 & 1.5 & 1.0 \\
\hline \multicolumn{7}{|c|}{ Straight-chain unsaturated fatty acids } \\
\hline $\mathrm{C}_{17: 1} \omega 8 c$ & & 0.2 & 1.0 & & & \\
\hline $\mathrm{C}_{18: 1} \omega 7 c$ & 50.4 & 68.0 & 67.4 & 58.5 & 77.9 & 65.1 \\
\hline \multicolumn{7}{|c|}{ Branched-chain saturated fatty acids } \\
\hline anteiso- $\mathrm{C}_{15: 0}$ & 0.5 & & & & & \\
\hline anteiso- $\mathrm{C}_{16: 0}$ & 0.5 & & & & & \\
\hline anteiso- $\mathrm{C}_{17: 0}$ & 0.5 & & & & & \\
\hline \multicolumn{7}{|l|}{ Hydroxy fatty acids } \\
\hline $\mathrm{C}_{10: 0} 3-\mathrm{OH}$ & 0.3 & 0.2 & & & 2.0 & 1.0 \\
\hline $\mathrm{C}_{12: 0} 2-\mathrm{OH}$ & & & 0.6 & & & 1.5 \\
\hline $\mathrm{C}_{12: 0} 3-\mathrm{OH}$ & 5.3 & 5.3 & & 2.3 & 0.1 & 0.3 \\
\hline $\mathrm{C}_{12: 1} 3-\mathrm{OH}$ & & & 2.6 & & & 2.8 \\
\hline $\mathrm{C}_{16: 0} 2-\mathrm{OH}$ & & & 0.9 & & & 4.6 \\
\hline $\mathrm{C}_{16: 0} 3-\mathrm{OH}$ & & & & & 0.6 & \\
\hline \multicolumn{7}{|l|}{ Methyl fatty acids } \\
\hline $\mathrm{C}_{18: 1} \omega 7 c$ 11-methyl & 9.3 & 0.8 & 6.1 & & 1.5 & 0.9 \\
\hline \multicolumn{7}{|l|}{ Cyclopropane acid } \\
\hline $\mathrm{C}_{19: 0} \omega 8 c$ cyclo & 0.6 & 1.5 & 0.2 & 14.2 & & 4.3 \\
\hline \multicolumn{7}{|l|}{ Summed features ${ }^{*}$} \\
\hline 3 & 1.6 & 0.6 & 0.6 & 1.5 & 2.2 & 1.0 \\
\hline 7 & 0.5 & & 0.3 & & & 1.3 \\
\hline $\begin{array}{l}\text { Unknown fatty acid (ECL } \\
11.799)\end{array}$ & 0.9 & 0.2 & & 0.6 & & 0.9 \\
\hline
\end{tabular}

${ }^{*}$ Summed features represent groups of two or three fatty acids that could not be separated by the MIDI system. Summed feature 3 contains $\mathrm{C}_{16: 1} \omega 7 c$ and/or iso- $\mathrm{C}_{15: 0}$ 2-OH. Summed feature 7 contains $\mathrm{C}_{19: 1} \omega 6 c, \mathrm{C}_{19: 0} \omega 10 c$ cyclo and/or unknown fatty acid ECL 18.846 .
(1995). The 16S rRNA gene was PCR-amplified with two universal primers, 5'-AGAGTTTGATCCTGGCTCAG-3' and $5^{\prime}$-ACGGCTACCTTGTTACGACT-3'. Purification and sequencing of PCR products were performed as described by Liu \& Shao (2005). A nearly full-length 16 S rRNA gene sequence (1422 bp) of strain $\mathrm{NH}_{2} \mathrm{~J}^{\mathrm{T}}$ was obtained and was compared with sequences retrieved from the GenBank database. Sequences were aligned using DNAMAN software (version 6) and evolutionary distances were calculated according to the Kimura two-parameter model analysis (Kimura, 1980). A phylogenetic tree was constructed by using the neighbour-joining method (Saitou \& Nei, 1987) and evaluated by bootstrap analysis based on 1000 replicates.

The DNA G + C content was determined to be $62 \mathrm{~mol} \%$ by reverse HPLC according to the method of Tamaoka \& Komagata (1984). This value is consistent with the $\mathrm{G}+\mathrm{C}$ range of the genus Roseovarius (58.6-66 mol\%).

Comparative 16S rRNA gene sequence analysis showed that strain $\mathrm{NH}_{52} \mathrm{~J}^{\mathrm{T}}$ was most closely related to the members of the genera Roseovarius, Leisingera, Phaeobacter and Marinovum within the class Alphaproteobacteria. Strain $\mathrm{NH}_{2} \mathrm{~J}^{\mathrm{T}}$ exhibited $16 \mathrm{~S}$ rRNA gene sequence similarity values of 95.2, 95.7, 94.7, 94.6, 93.9, 93.6, 94.0, 93.7 and 93.1\% with respect to the type strains of Roseovarius pacificus, Roseovarius aestuarii, Roseovarius mucosus, Roseovarius nubinhibens, Roseovarius crassostreae, Roseovarius tolerans, Leisingera methylohalidivorans, Marinovum algicola and Phaeobacter gallaeciensis, respectively. Moreover, the $16 \mathrm{~S}$ rRNA sequence similarities with other species were less than $94.0 \%$. A phylogenetic tree constructed by using the neighbour-joining algorithm indicated that strain $\mathrm{NH} 52 \mathrm{~J}^{\mathrm{T}}$ was unambiguously affiliated to the genus Roseovarius in a distinct clade. Within this clade, strain $\mathrm{NH}_{52} \mathrm{~J}^{\mathrm{T}}$ and the following species Rva. pacificus, Rva. aestuarii, Rva. nubinhibens and Rva. crassostreae formed a clearly separate subclade, which was grouped together with other species of the genus Roseovarius (Fig. 1). The results of the phylogenetic analysis and the relatively low 16S rRNA gene sequence similarity to species of the genus Roseovarius suggest that strain $\mathrm{NH}_{2} \mathrm{~J}^{\mathrm{T}}$ represents a novel species within the genus Roseovarius.

The hydroxylated fatty acids $\mathrm{C}_{12: 0} 2-\mathrm{OH}, \mathrm{C}_{12: 0} 3-\mathrm{OH}$ and $\mathrm{C}_{12: 1} 3-\mathrm{OH}$ have been indicated as being characteristic of the genus Roseovarius (Biebl et al., 2005). Fatty acid $\mathrm{C}_{12: 0}$ $3-\mathrm{OH}$ was present in strain $\mathrm{NH} 52 \mathrm{~J}^{\mathrm{T}}$ and the following four strains, Rva. aestuarii, Rva. nubinhibens, Rva. crassostreae and Rva. mucosus, whereas Rva. tolerans contained fatty acids $\mathrm{C}_{12: 1} 3-\mathrm{OH}$ and $\mathrm{C}_{12: 0} 2-\mathrm{OH}$ instead. For $R v a$. mucosus, hydroxylated fatty acids $\mathrm{C}_{12: 0} 2-\mathrm{OH}, \mathrm{C}_{12: 0} 3-\mathrm{OH}$ and $\mathrm{C}_{12: 1} 3-\mathrm{OH}$ were all detected. The very similar major fatty acid composition also supported the placement of the novel isolate within the genus Roseovarius (Table 2). Strain $\mathrm{NH}_{22}{ }^{\mathrm{T}}$ was distinguishable from other species of the genus Roseovarius by fatty acid $\mathrm{C}_{17: 0}$, which was absent in this strain, and the presence of branched-chain fatty acids 


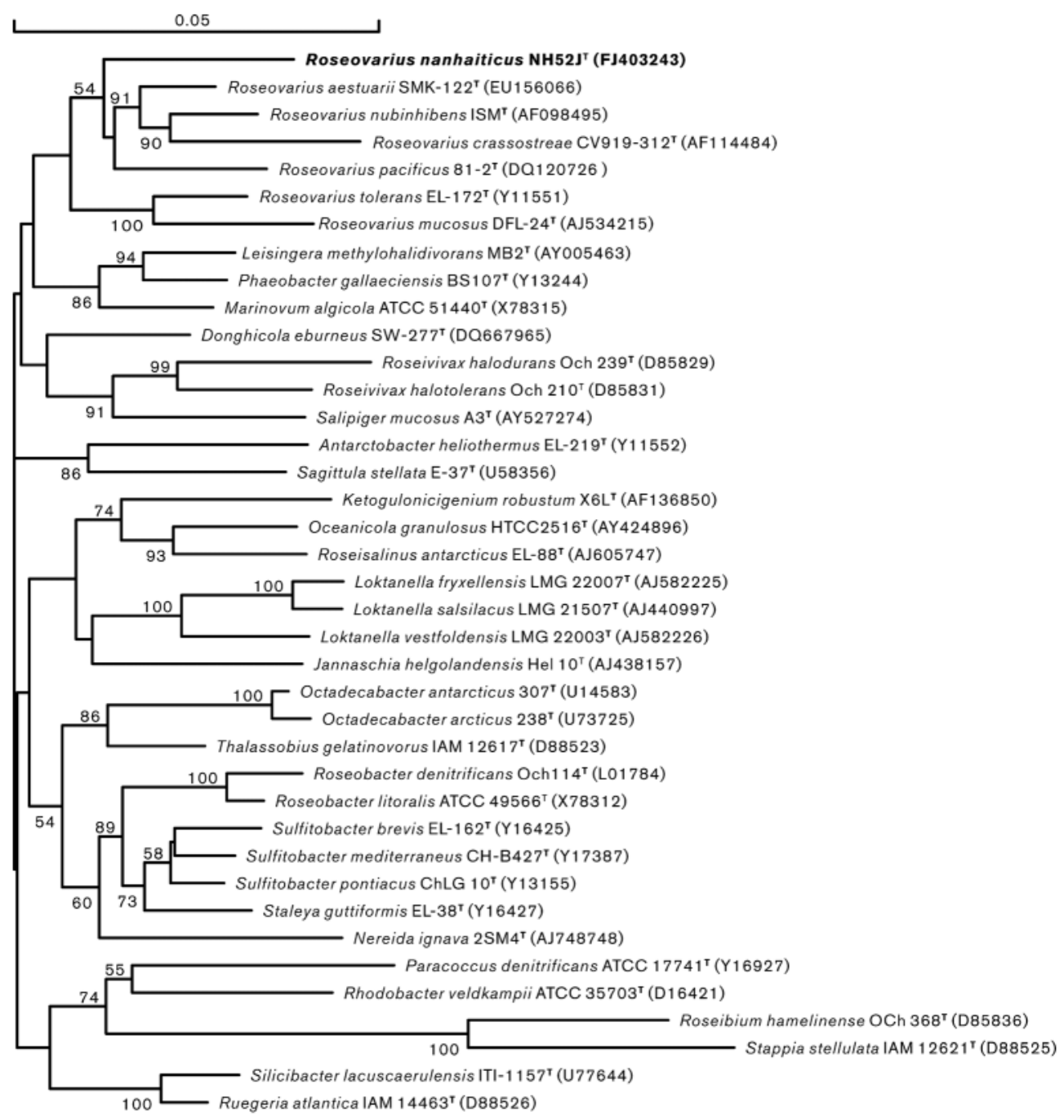

Fig. 1. Phylogenetic tree based on the $16 \mathrm{~S}$ rRNA gene sequences of strain $\mathrm{NH} 52 \mathrm{~J}^{\mathrm{T}}$ and representative members of the family Rhodobacteraceae within the class Alphaproteobacteria. The tree was generated by the neighbour-joining method (Saitou \& $\mathrm{Nei}, 1987$ ). Bootstrap values above $50 \%$ (1000 replicates) are indicated at the nodes. GenBank accession numbers are shown in parentheses. Bar, 0.05 substitutions per nucleotide position.

that were only found in the novel isolate, such as anteiso$\mathrm{C}_{15: 0}$, anteiso- $\mathrm{C}_{16: 0}$ and anteiso- $\mathrm{C}_{17: 0}$. The fatty acid data, as well as the results of phylogenetic analyses, support the classification of strain $\mathrm{NH}_{52} \mathrm{~J}^{\mathrm{T}}$ as a novel species of the genus Roseovarius.

The phenotypic characteristics of strain $\mathrm{NH}_{52} \mathrm{~J}^{\mathrm{T}}$ are given in the species description below. Growth occurred at $\mathrm{NaCl}$ concentrations of $0.5-10.0 \%(\mathrm{w} / \mathrm{v})$, but was not observed without $\mathrm{NaCl}$ or at $\mathrm{NaCl}$ concentrations higher than $13.0 \%(\mathrm{w} / \mathrm{v})$. Optimal growth occurred at 2.0 $4.0 \%(\mathrm{w} / \mathrm{v}) \mathrm{NaCl}$. Within the tested temperature range $\left(4-45{ }^{\circ} \mathrm{C}\right)$, growth occurred between $9{ }^{\circ} \mathrm{C}$ and $37{ }^{\circ} \mathrm{C}$, with maximum growth at $30{ }^{\circ} \mathrm{C}$. The optimal $\mathrm{pH}$ for growth was 7.8-9.3; weak growth occurred at $\mathrm{pH} 6.5$ and 9.7, but no growth occurred at $\mathrm{pH} 6.0$ or 10.0. Other differences in phenotypic characteristics between strain $\mathrm{NH}_{5} \mathrm{~J}^{\mathrm{T}}$ and some phylogenetically related members of the Roseobacter clade are shown in Table 1. The low $16 \mathrm{~S}$ rRNA gene sequence similarity, together with differences found in chemotaxonomic, physiological and biochemical analyses, indicates that isolate $\mathrm{NH}_{2} \mathrm{~J}^{\mathrm{T}}$ should be classified in the genus Roseovarius as a novel species. The name Roseovarius nanhaiticus sp. nov. is proposed.

\section{Description of Roseovarius nanhaiticus sp. nov.}

Roseovarius nanhaiticus (nan.hai'ti.cus. N.L. masc. adj. nanhaiticus referring to Nanhai, the South China Sea, the site from where the type strain was isolated).

Cells are aerobic, Gram-staining-negative, non-sporeforming and ovoid to rods with a size of 0.58$0.84 \times 1.42-3.37 \mu \mathrm{m}$ (Fig. 2). Cells show predominantly 


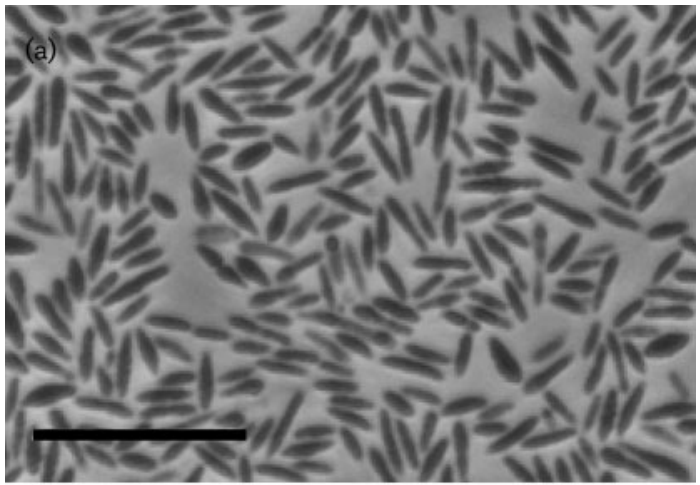

(b)



Fig. 2. Morphology of cells of strain $\mathrm{NH}^{2} 2 \mathrm{~J}^{\top}$ grown on an $\mathrm{M} 2$ agar plate for $24 \mathrm{~h}$ at $30{ }^{\circ} \mathrm{C}$. (a) Phase-contrast micrograph; bar, $10 \mu \mathrm{m}$. (b-c) transmission electron micrographs of negatively stained cells; bars, $1 \mu \mathrm{m}$.

tumbling motion. Flagella are not found. On M2 agar plates, small, wettish, smooth, beige or faint pink colonies develop that are $0.5-1.0 \mathrm{~mm}$ in diameter within 3-5 days incubation at $30{ }^{\circ} \mathrm{C}$. Optimal growth is observed at $30{ }^{\circ} \mathrm{C}$, at salinities of $2.0-4.0 \%$ and at $\mathrm{pH}$ values between 7.8 and 9.3. There is an absolute requirement for sodium ions. Bacteriochlorophyll $a$ is not detected. Oxidase and catalase reactions are positive. Nitrate reduction, hydrolysis of starch, Tween 20, 40 and 80, gelatin liquefaction and urease activity are negative. $\mathrm{H}_{2} \mathrm{~S}$ and indole are not produced. Voges-Proskauer reaction is positive. Tests for arginine dihydrolase, lysine decarboxylase, ornithine decarboxylase, $\beta$-galactosidase and tryptophan deaminase are negative. In assays with API ZYM strips, alkaline phosphatase, esterase (C4), esterase lipase (C8), leucine arylamidase, valine arylamidase and cystine arylamidase are positive, but lipase (C14), trypsin, $\alpha$-chymotrypsin, acid phosphatase, naphthol-AS-BI-phosphohydrolase, $\alpha$ galactosidase, $\beta$-glucuronidase, $\alpha$-glucosidase, $N$-acetyl- $\beta$ glucosaminidase, $\alpha$-mannosidase and $\alpha$-fucosidase are negative. Cells are fastidious and grow well on seawaterbased complex medium, i.e. with yeast extract, tryptone and potato peptone as the substrates. According to the API 20NE strip, D-glucose, L-arabinose, D-mannose, D-mannitol, $\mathrm{N}$-acetylglucosamine, maltose, potassium gluconate, capric acid, adipic acid, malic acid, citrate and phenylacetic acid are not utilized as sole carbon sources. Acid is not produced from inositol, D-sorbitol, L-rhamnose, sucrose, melibiose or amygdalin in the API 20E system. In addition, the type strain is susceptible to cefoperazone, ciprofloxacin, ceftriaxone, erythromycin, cephalexin, ampicillin, kanamycin, norfloxacin, cephazolin, minocycline, carbenicillin, streptomycin, ofloxacin, rifampicin, piperacillin, penicillin G, chloramphenicol, cephradine and gentamicin, but resistant to polymyxin B, clindamycin, lincomycin, furazolidone, doxycycline hydrochloride, tetracycline, metronidazole, vancomycin, trimethoprim, oxacillin and neomycin. The predominant fatty acids are $(>5 \%$ of total fatty acids): $\mathrm{C}_{18: 1} \omega 7 c, \mathrm{C}_{16: 0}, \mathrm{C}_{12: 0}, \mathrm{C}_{18: 1} \omega 7 c$ 11-methyl and $\mathrm{C}_{12: 0}$ $3-\mathrm{OH}$. Other phenotypic characteristics are given in Table 1.

The type strain, $\mathrm{NH}_{52} \mathrm{~J}^{\mathrm{T}}$ (=LMG $24840^{\mathrm{T}}=\mathrm{CCTCC}$ AB $208317^{\mathrm{T}}=$ MCCC $1 \mathrm{~A} 03543^{\mathrm{T}}$ ), was isolated from a sandy sediment sample of the South China Sea at a depth of $157 \mathrm{~m}$. The DNA $\mathrm{G}+\mathrm{C}$ content of the type strain is $62 \mathrm{~mol} \%$.

\section{Acknowledgements}

This work was financially supported by National Key Technology R\&D Program of China (No. 2006BAB19B02), and National Infrastructure of Natural Resources for Science and Technology Program of China (No. 2005DKA21209).

\section{References}

Ausubel, F. M., Brent, R., Kingston, R. E., Moore, D. D., Seidman, J. G., Smith, J. A. \& Struhl, K. (editors) (1995). Short Protocols in Molecular Biology: a Compendium of Methods from Current Protocols in Molecular Biology, 3rd edn. New York: Wiley.

Biebl, H., Allgaier, M., Lünsdorf, H., Pukall, R., Tindall, B. J. \& Wagner-Döbler, I. (2005). Roseovarius mucosus sp. nov., a member of the Roseobacter clade with trace amounts of bacteriochlorophyll $a$. Int J Syst Evol Microbiol 55, 2377-2383.

Boettcher, K. J., Geaghan, K. K., Maloy, A. P. \& Barber, B. J. (2005). Roseovarius crassostreae sp. nov., a member of the Roseobacter clade and the apparent cause of juvenile oyster disease (JOD) in cultured Eastern oysters. Int J Syst Evol Microbiol 55, 1531-1537.

Buchan, A., González, J. M. \& Moran, M. A. (2005). Overview of the marine Roseobacter lineage. Appl Environ Microbiol 71, 5665-5677.

Cowan, S. T. \& Steel, K. J. (1965). Manual for the Identification of Medical Bacteria. London: Cambridge University Press.

Dai, X., Wang, B. J., Yang, O. X., Jiao, N. Z. \& Liu, S. J. (2006). Yangia pacifica gen. nov., sp. nov., a novel member of the Roseobacter clade from coastal sediment of the East China Sea. Int J Syst Evol Microbiol 56, 529-533.

Gerhardt, P., Murray, R. G. E., Wood, W. A. \& Krieg, N. R. (editors) (1994). Methods for General and Molecular Bacteriology. Washington, DC: American Society for Microbiology.

González, J. M., Covert, J. S., Whitman, W. B., Henriksen, J. R., Mayer, F., Scharf, B., Schmitt, R., Buchan, A., Fuhrman, J. A. \& other authors (2003). Silicibacter pomeroyi sp. nov. and Roseovarius nubinhibens sp. nov., dimethylsulfoniopropionate-demethylating bacteria from marine environments. Int J Syst Evol Microbiol 53, 1261-1269.

Hwang, C. Y. \& Cho, B. C. (2008). Ponticoccus litoralis gen. nov., sp. nov., a marine bacterium in the family Rhodobacteraceae. Int J Syst Evol Microbiol 58, 1332-1338. 
Kimura, M. (1980). A simple method for estimating evolutionary rates of base substitutions through comparative studies of nucleotide sequences. J Mol Evol 16, 111-120.

Labrenz, M., Collins, M. D., Lawson, P. A., Tindall, B. J., Schumann, P. \& Hirsch, P. (1999). Roseovarius tolerans gen. nov., sp. nov., a budding bacterium with variable bacteriochlorophyll $a$ production from hypersaline Ekho Lake. Int J Syst Bacteriol 49, 137-147.

Lafay, B., Ruimy, R., Rausch de Traubenberg, C., Breittmayer, V., Gauthier, M. J. \& Christen, R. (1995). Roseobacter algicola sp. nov., a new marine bacterium isolated from the phycosphere of the toxin-producing dinoflagellate Prorocentrum lima. Int J Syst Bacteriol 45, 290-296.

Lee, K., Choo, Y. J., Giovannoni, S. J. \& Cho, J. C. (2007). Maritimibacter alkaliphilus gen. nov., sp. nov., a genome-sequenced marine bacterium of the Roseobacter clade in the order Rhodobacterales. Int J Syst Evol Microbiol 57, 1653-1658.

Liu, C. \& Shao, Z. (2005). Alcanivorax dieselolei sp. nov., a novel alkane-degrading bacterium isolated from sea water and deep-sea sediment. Int J Syst Evol Microbiol 55, 1181-1186.

Martens, T., Heidorn, T., Pukall, R., Simon, M., Tindall, B. J. \& Brinkhoff, T. (2006). Reclassification of Roseobacter gallaeciensis RuizPonte et al. 1998 as Phaeobacter gallaeciensis gen. nov., comb. nov., description of Phaeobacter inhibens sp. nov., reclassification of Ruegeria algicola (Lafay et al. 1995) Uchino et al. 1999 as Marinovum algicola gen. nov., comb. nov., and emended descriptions of the genera Roseobacter, Ruegeria and Leisingera. Int J Syst Evol Microbiol 56, 1293-1304.

Martínez-Cánovas, M. J., Quesada, E., Martínez-Checa, F., del Moral, A. \& Bejar, V. (2004). Salipiger mucescens gen. nov., sp. nov., a moderately halophilic, exopolysaccharide-producing bacterium isolated from hyper- saline soil, belonging to the $\alpha$-Proteobacteria. Int J Syst Evol Microbiol 54, 1735-1740.

Ruiz-Ponte, C., Cilia, V., Lambert, C. \& Nicolas, J. L. (1998). Roseobacter gallaeciensis sp. nov., a new marine bacterium isolated from rearings and collectors of the scallop Pecten maximus. Int J Syst Bacteriol 48, 537-542.

Saitou, N. \& Nei, M. (1987). The neighbour-joining method: a new method for reconstructing phylogenetic trees. Mol Biol Evol 4, 406425.

Sambrook, J., Fritsch, E. F. \& Maniatis, T. (1989). Molecular Cloning: a Laboratory Manual, 2nd edn. Cold Spring Harbor, NY: Cold Spring Harbor Laboratory.

Schaefer, J. K., Goodwin, K. D., McDonald, I. R., Murrell, J. C. \& Oremland, R. S. (2002). Leisingera methylohalidivorans gen. nov., sp. nov., a marine methylotroph that grows on methyl bromide. Int J Syst Evol Microbiol 52, 851-859.

Tamaoka, J. \& Komagata, K. (1984). Determination of DNA base composition by reversed-phase high-performance liquid chromatography. FEMS Microbiol Lett 25, 125-128.

Wagner-Döbler, l., Rheims, H., Felske, A., Pukall, R. \& Tindall, B. J. (2003). Jannaschia helgolandensis gen. nov., sp. nov., a novel abundant member of the marine Roseobacter clade from the North Sea. Int J Syst Evol Microbiol 53, 731-738.

Wang, B., Tan, T. \& Shao, Z. (2009). Roseovarius pacificus sp. nov., isolated from deep-sea sediment. Int J Syst Evol Microbiol 59, 1116-1121.

Yoon, J.-H., Kang, S.-J. \& Oh, T.-K. (2008). Roseovarius aestuarii sp. nov., isolated from a tidal flat of the Yellow Sea in Korea. Int J Syst Evol Microbiol 58, 1198-1202. 